\title{
ロックフィルダムの実測応カならびに ひずみ挙動に関する検討
}

\author{
佐藤信光 ${ }^{1} \cdot$ 米崎文雄 $2 \cdot$ 大藪勝美 ${ }^{3} \cdot$ 太田秀樹 $4 \cdot$ ・ 中川浩二 5 \\ 1 正会員 独立行政法人水資源機構 技術研究研修センター(テ 338-0812 埼玉県さいたま市桜区神田 936) \\ nobuteru_sato@water.go.jp \\ 2 財団法人ダム技術センター 研究第二部（テ 106-0041 東京都港区麻生台 2-4-5） \\ yonezaki@jdec.or.jp \\ 3 正会員 独立行政法人水資源機構（† 330-6008 埼玉県さいたま市中央区新都心 11-2) \\ katsumi_ooyabu@water.go.jp \\ 4 フェロー会員 工博 東京工業大学教授 大学院理工学研究科( \\ ohta@cv.titech.ac.jp \\ 5 フェロー会員 工博 山口大学教授 工学部社会建設工学科( 7 755-8611 山口県宇部市常盤台 2-16-1) \\ nakagawa@ rock.civil.yamaguchi-u.ac.jp
}

\begin{abstract}
ロックフィルダムのカ学的挙動の課題として, フィルタ部への応力集中とコア部の応力低下, 地震に対する堤体 の耐震性能照査法の高度化ならびにコンクリート表面遮水壁型ロックフィルダムへの新たな取り組みなどがあり, 堤 体挙動解析手法の高度化が進められている. 本研究は, 上記課題を考慮して堤体挙動評価の基本となる静的挙 動のうち, 実測された応力ならびにひずみ挙動について検討した. 4つのロックフィルダムにおける築堤および湛水 時の堤体挙動記録を全般にわたって比較分析し, その中から上記課題に資する堤体挙動評価の可能性をとりまと めた. その結果, 今後のダム設計の見直しや堤体挙動解析の高度化に資する有益な知見を提示した.
\end{abstract}

Key Words : rock-fill dam, stress and strain behavior, embankment, filling action, dam-body observation

\section{1. はじめに}

ロックフィルダムには, 施工時や湛水時のすべりや浸 透破壊などに対する堤体の安全性の評価や有限要素 法を用いた堤体挙動解析による耐震性能照査など, 今 後のダム設計の高度化のために, 多くの観測計器が堤 体内に設置されている. 現在, この観測計器によって築 堤および湛水時の実測挙動記録が蓄積され，その実測 記録からフィルタ部への応力集中とコア部の応力低下 の課題が論じられている ${ }^{1), 2}$. また, 強い地震動に対する 堤体の耐震性能照査法の高度化や ${ }^{3)}$, 建設コス卜縮減 の一環としてコンクリート表面遮水壁型ロックフィルダム への新たな取り組み ${ }^{4) .5}$ などの課題があり,これらの対応 のために, 従来の Duncan らの近似式による方法 ${ }^{6)}$ や弾 粘塑性モデルによる方法 "7を用いた逐次築堤解析な ど, 有限要素法を用いた堤体挙動解析手法の高度化
'が進められている.

ロックフィルダムは一般にダム高約 $50 \mathrm{~m} 〜 150 \mathrm{~m}$ で, 最大粒径約 $1 \mathrm{~m}$ の粗粒材料のロック部, 土質材料のコ ア部ならびにそれらの中間的粒度のフィルタ部からなる 複合構造をした大規模構造物である. そのため力学的 に未解明な分野を多く含み, 堤体挙動解析の高度化に 当たつてはロックフィルダムの種々挙動を実測值から評 価することが重要である ${ }^{31}$.これまでに, 多くのダムの実 測記録を総括的に評価した研究事例や個別のダムの 実測挙動を詳細に検討した事例はあつた ${ }^{2,88,99,10)}$. しか し, 今後の堤体設計の見直しや特に堤体挙動解析の高 度化に当たっては, 個別ダムの挙動評価だけでなく, 複 数のダムの堤体挙動を全般にわたって分析し, その中 から今後の設計の見直しや高度化に資する堤体挙動 特性の可能性を評価することが重要である.

本研究では, 上記課題を考慮して堤体挙動評価の 
基本となる静的挙動のうち, 先に報告したロックフィルダ ムの実測変形挙動の検討 ${ }^{111}$ に引き続き, 実測応力なら びにひずみ挙動を検討することとした. 本検討は, 水資

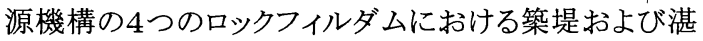
水時の堤体挙動記録を全般にわたって比較分析し, 堤 体の耐震性能照査法の高度化, フィルタ部の応力集中 とコア部の応力低下ならびにコンクリート表面遮水壁型 ロックフィルダムへの取り組みの課題に対して, 今後の ダムの設計の見直しや堤体挙動解析の高度化に資す る堤体挙動評価の可能性を取りまとめることとした.

\section{2. ロックフィルダムのカ学挙動評価の課題}

先に示したロックフィルダムの課題を力学挙動評価の 観点で以下にまとめた.

(1)地震に対する堤体の耐震性能照査法の高度化

1995 年兵庫県南部地震以降, 強い地震動に対する ダムの耐震性を動的解析により照査する取り組みが進 められている.この動的解析では, 地震前の応力状態と 地震時の応力状態を重ね合わせて評価することがほと んぞである.よって, ダムのような大規模構造物における 地震時の最大応力状態の算定に際しては, 初期応力 の影響が比較的大きく, 地震時だけでなく地震前の応 力状態を精度よく把握することが大切である ${ }^{12), 13)}$. 特に, 地震によるロックフィルダムの堤体損傷の事例をみると, 堤頂部のクラック発生や法肩崩れ，堤体沈下などが報 告されている ${ }^{14)}$. コア部の土質材の動的強度や残留変 形特性は初期応力の影響を受けることからら ${ }^{14), 15)}$, 地震前 のコア部の初期応力分布を適切に評価することが重要 である.

(2)フィルタ部の応力集中とコア部の応力低下

ロックフィルダムはコア部とフィルタ部の剛性の違いや フィルタ部のアーチ効果から, フィルタ部への応力集中 とコア部の応力低下が指摘されている.このため, コア 部の応力低下に伴って, 湛水時の浸透破壊に対する安 全性を懸念する考え方がある ${ }^{16)}$. また，上流ロック部の 浸水沈下に伴ってコア部の不等沈下や変形が生じ ${ }^{17}$, フィルタ部やコア部の応力状態に影響を及ぼす可能性 もある.これに対して, 築堤時ならびに湛水時のフィルタ 部とコア部の応力分布の実態や応力低下の程度などを 把握する必要がある.

(3)コンクリート表面遮水壁型ロックフィルダム

最近では, 建設コスト縮減の観点からコンクリート表面 遮水壁型ロックフィルダムの研究が取り組まれている.こ のダムでは, 貯水を上流面のコンクリートスラブで遮水し て貯水圧をロック部で支える構造となっている.このた め, ロック部が予想以上に変形するとコンクリートスラブ

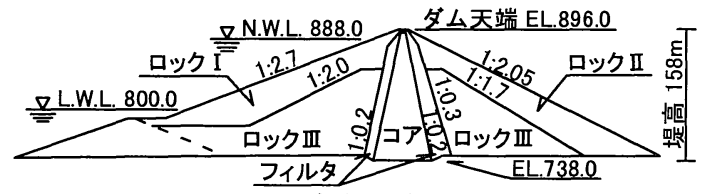

A）奈良俣ダム

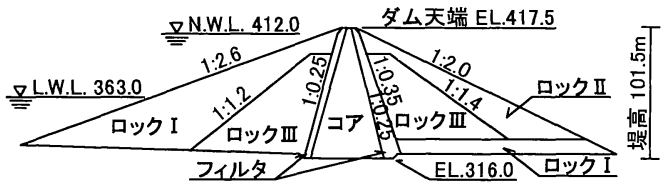

B) 阿木川ダム

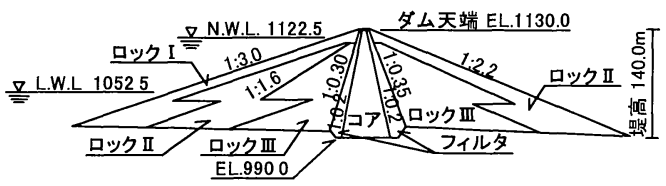

C) 味噌川ダム

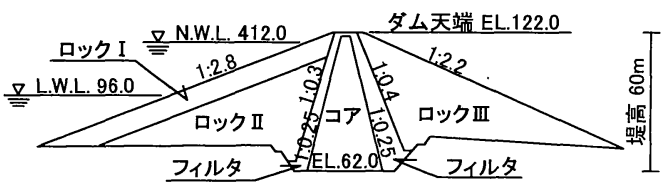

D) 山口調整池

図-1 堤体の標淮断面 ${ }^{11)}$

の継目が過度に開口し, 漏水の要因となる可能性があ る. 従来, 中央土質遮水壁型ロックフィルダムでは, ロッ ク部に対して応力や強度, 動的な非線形特性に着目し て研究が進められてきた ${ }^{3,122}$. しかし, コンクリート表面遮 水壁型ロックフィルダムでは, ロック部の変形性評価が 重要で ${ }^{18}$, 特に将来期待される堤高の高いダムでは口 ック部の応力ひずみ特性を精度よく把握することが求め られる。

(4)ロックフィルダムの堤体挙動解析の高度化

上記課題に対応するためには, 築堤および湛水時の 堤体挙動を精度よく再現する必要がある.このため, 有 限要素法などによる解析の高度化が図られつつある.こ の解析では, 各ダムの堤体に発生する各ゾーンの応力 分布, ひずみのばらつきならびに応力ひずみの経路に 対して, 実測值から堤体挙動を評価し, 解析の高度化 につなげていく必要がある.

本検討では, 上記課題を踏まえて, ロックフィルダム の力学的挙動のうち堤体挙動評価の基本となる静的挙 動に着目して実測值から検討を行うこととし, 実測変形 挙動の検討 ${ }^{111}$ に引き続き, 堤体の応力分布, ひずみ分 布, ならびに応力ひずみ経路を分析することとした. 本 検討は, 図-1に示す水資源機構の 4 ダムにおける築 堤および湛水時の堤体挙動を比較し, 各ダムで共通す 
表一 1 ロックフィルダムの諸元 ${ }^{11)}$

\begin{tabular}{|c|c|c|c|c|c|}
\hline \multicolumn{2}{|l|}{ ダム名 } & 奈良俣ダム & 阿木川ダム & 味増川ダム & 山口調整池 \\
\hline 堤高 & $m$ & 158 & 101.5 & 140 & 60 \\
\hline 堤頂長 & $\mathrm{m}$ & 520 & 362 & 447 & 326 \\
\hline 堤体糟 & $\mathrm{m}^{3}$ & $13,100,000$ & $4,900,000$ & $8,900,000$ & $1,060,000$ \\
\hline 堤頂摆高 & EL.m & 896.0 & 417.5 & 1130.0 & 122.0 \\
\hline 常時㴖水位 & EL.m & 888.0 & 412.0 & 1122.5 & 118.0 \\
\hline 制限水位 & EL.m & 881.0 & 400.5 & 1113.0 & - \\
\hline 最低水位 & EL.m & 800.0 & 363.0 & 1052.0 & 96.0 \\
\hline コア敷檈高 & EL.m & 738.0 & 316.0 & 990.0 & 62.0 \\
\hline タム軸半经 & & 直楾 & $\mathrm{R} 800 \mathrm{~m}$ & $\mathrm{R} 1000 \mathrm{~m}$ & 直楾 \\
\hline \multicolumn{2}{|l|}{ 堤頂長／堤高 } & 3.3 & 3.6 & 3.2 & 5.4 \\
\hline \multicolumn{2}{|l|}{ 笲堤開始 } & $1983 / 10 / 15$ & $1986 / 3 / 16$ & $1986 / 8 / 7$ & $1994 / 12 / 22$ \\
\hline \multicolumn{2}{|l|}{ 筑堤終了 } & $1988 / 6 / 6$ & $1988 / 2 / 15$ & $1993 / 6 / 3$ & $1996 / 4 / 27$ \\
\hline \multicolumn{2}{|l|}{ 試験湛水開始 } & $1988 / 10 / 4$ & $1989 / 10 / 2$ & $1993 / 12 / 10$ & $1997 / 11 / 6$ \\
\hline \multicolumn{2}{|l|}{ 最高水位到達 } & $1991 / 5 / 28$ & $1991 / 1 / 25$ & $1996 / 4 / 30$ & $1998 / 12 / 1$ \\
\hline \multicolumn{2}{|l|}{ 試医湛水終了 } & $1991 / 6 / 22$ & $1991 / 5 / 7$ & $1996 / 8 / 3$ & $1999 / 2 / 4$ \\
\hline \multicolumn{2}{|l|}{ 現時点 } & $1999 / 12 / 2$ & $2000 / 11 / 6$ & $2000 / 12 / 18$ & $2001 / 1 / 9$ \\
\hline 筑堤期間 & 日 & 1696 & 701 & 2492 & 492 \\
\hline 築堤完了～湛水開始 & 日 & 120 & 595 & 190 & 558 \\
\hline 試酫湛水期間 & 旦 & 991 & 582 & 967 & 455 \\
\hline 築堤完了〜現時点 & 日 & 4196 & 4648 & 2755 & 1718 \\
\hline 湛水開始～現時点 & 旦 & 4076 & 4053 & 2565 & 1160 \\
\hline
\end{tabular}

る挙動特性や個々のダムで異なる特徴的な挙動を分析 して, 上記課題に資する堤体挙動評価の可能性をとり まとめた. なお, 本検討は複数のダムによる全般的な実 測挙動を主体とすることから，材料特性等の詳細な検 討は紙面の関係から含めていない. また, コア部の応力 は全応力と間隙水圧を考慮した有効応力に分けられる が, 間隙水圧の評価とともに全応力を十分評価すること が適切な有効応力の評価にもつながることから, 本検討 では全応力を優先して行った.

\section{3. 対象ダムの概要と堤体観測記録}

水資源機構においては, 奈良俣ダム(堤高 $158 \mathrm{~m}$ ), 味増川ダム (堤高 $140 \mathrm{~m}$ )，阿木川ダム(堤高 $101.5 \mathrm{~m}$ ), 山口調整池 (堤高 $60 \mathrm{~m}$ ) が最近約 10 年間 に完成した.この 4 ダムでは, 築堤時の施工管理, 完成 後の挙動管理, 今後のダムの設計高度化のために多く の観測計器を配置し, 築堤時の挙動や湛水後約 10 年 間の挙動を詳細に観測している. さらに, その都度, 観 測計器の点検や観測記録の信頼性の確認を行ってい る.このうち, 堤体応力ならびにひずみに関する観測記 録を用いて, 実測応力ならびにひずみ挙動を比較評価 することとした.これらの4つのロックフィルダムの諸元を 表一 1 に, 堤体の標準断面を図一 1 に示す.いずれの ダムも中央土質遮水壁型ロックフィルダムである.

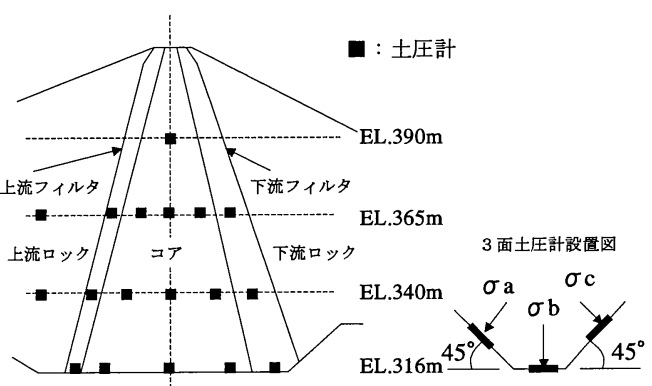

図一2 阿木川ダムにおける土圧計の配置
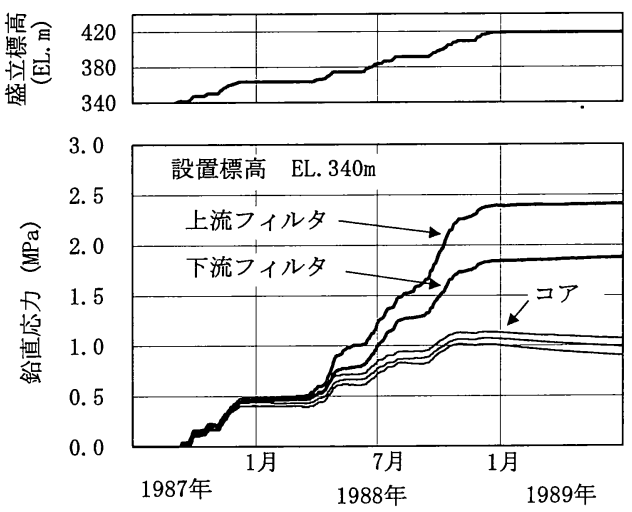

図ー3阿木川ダムにおける盛立標高と 鉛直応力の経時変化

\section{4. 堤体の応力挙動}

\section{(1) 築堤時の応力}

\section{a) 鉛直応力の経時変化}

ロックフィルダムでは堤体内の応力状態を把握するた めに, 図一 2 に示すように築堤途中で堤体内に土圧計 を設置している. まず, 課題として上げられているフィル タ部への応力集中とコア部の応力低下に着目して検討 する.

図ー2に示すように阿木川ダムでは異なる4標高に 土圧計が設置され, コア部とフィルタ部の応力分布が比 較できるようになっている.この土圧計は3面土圧計で, 底面土圧計を用いて鉛直応力を測定し, 上下流 $45^{\circ}$ の側面土圧計の応力と組み合わせて最大主応力およ び最小主応力の大きさと方向を求めることができるとさ れている. しかし, 土圧計の計器自体の剛性の問題やト レンチ掘削による設置方法の問題, 大粒径材料への適 用性などから, その計測值をそのまま堤体内の応力状 態として評価することへの問題も指摘されている ${ }^{19}$. ま た, 側面土圧計は傾斜地盤の沈下等によって計測值に 


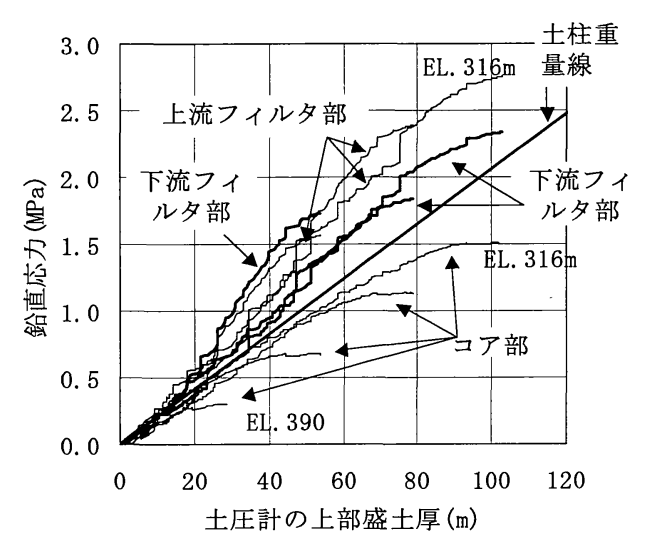

図-4 阿木川ダムの土被り厚と鉛直応力の関係

誤差を生じやすい. よって, 比較的信頼性のあると考え られる底面土圧計の計測值 (鉛直応力)のみを検討対 象として用いることとした.

図ー3に阿木川ダムのコア部およびフィルタ部の鉛 直応力の経時変化を示す. 上図は土圧計上部の盛立 標高の経時変化で, 下図は堤体の EL.340m に設置さ れた土圧計の鉛直応力の経時変化である. 盛立初期 は, コア部およびフィルタ部の鉛直応力は同程度の増 加傾向を示していたが, 盛立標高 EL.360m 付近より上 部の盛立からフィルタ部の鉛直応力の増加傾向が大き くなり, コア部の鉛直応力と差が生じている. 上下流フィ ルター部の鉛直応力は, 上流側が大きく下流側が小さ い傾向を示し, 盛立の進行とともにフィルタ部への応力 集中が顕著になっている. 築堤完了後にコア部の鉛直 応力が低下傾向を示している挙動については後節で詳 述する.

\section{b) 土被り厚と鉛直応力の增加}

図一 3 で示した盛立標高と鉛直応力の経時変化に 対して, 鉛直応力増加の要因となる土被り厚と鉛直応 力の関係を図 -4 に示す. 図ー4 は阿木川ダムにおけ るコア・フィルタ部の各標高に設置された土圧計の鉛直 応力と土圧計上部の土被り厚の経時変化を示したもの で, 縦軸が鉛直応力, 横軸が土圧計上部の土被り厚さ である. 図ー4には施工管理で得られた堤体の平均単 位体積重量 $\left(\gamma_{\mathrm{t}}=20.6 \mathrm{kN} / \mathrm{m}^{3}\right)$ に土圧計上部の土被り厚 を乗じて求めた土柱重量線も併記している. 標記してい るコア部の鉛直応力は, 図一 2 に示すコア部中央に設 置した EL.316，340，365，390m の4標高の計測值 である. EL. $316 \mathrm{~m}$ の土圧計は鉛直応力が $1.5 \mathrm{MPa}$ ま で, EL.390m が 0.3MPa まで増加している. コア部の鉛 直応力は, 盛立初期では土被り厚の増加とともに鉛直 応力が土柱重量線と同程度に増加しているが, 盛立後
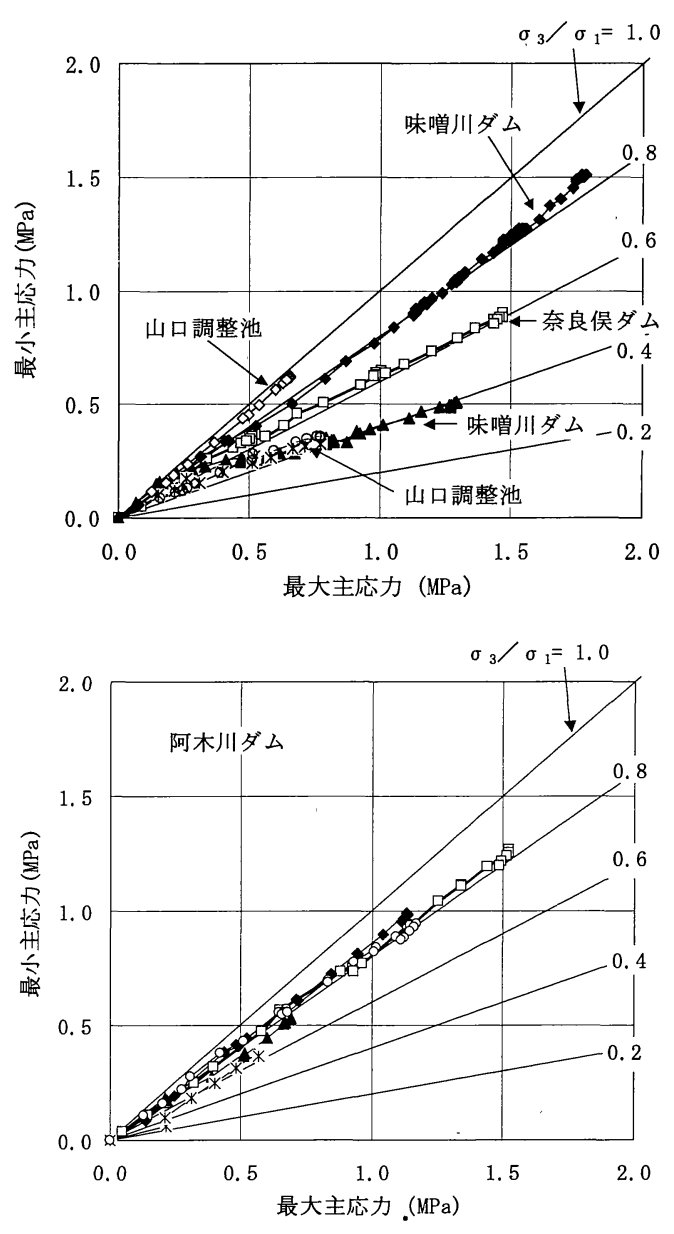

図一 5 築堤時のコア部の応力経路

半で各標高の鉛直応力が土柱重量線と比較して顕著 に低下する傾向を示している. フィルタ部の鉛直応力は 土被り厚の小さい時から土柱重量線を越えて増加して いるが, 盛立後半ではフィル夕部の鉛直応力もコア部と 同様に増加傾向が顕著に低下する傾向を示している.

コア部ならびにフィルタ部の鉛直応力の増加傾向が 低下傾向を示す時期は, 堤頂部付近の盛立時期に該 当する.この理由として, 以下の要因が考えられる. 堤 体形状は図ー1に示すように三角形で, 盛立は下部か ら層状に逐次盛立される.このため, 各土圧計が設置さ れた直上の盛立では, 水平層状に近い盛土荷重が土 圧計に作用する. しかし, 堤頂部付近の盛立では上下 流方向の盛立幅が小さく三角形形状の盛土荷重しか土 圧計に作用せず, 鉛直応力の増加傾向が顕著に低下 してくると考えられる.

また, フィルタ部の鉛直応力が土被り厚の小さい時期 から共通して土柱重量線よりも顕著に増加していること については, フィルタへの応力集中が土被り厚の小さい 


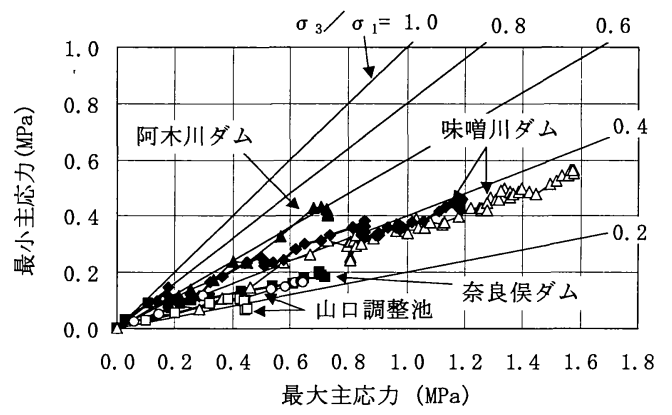

図-6 築堤時のロック部の応力経路
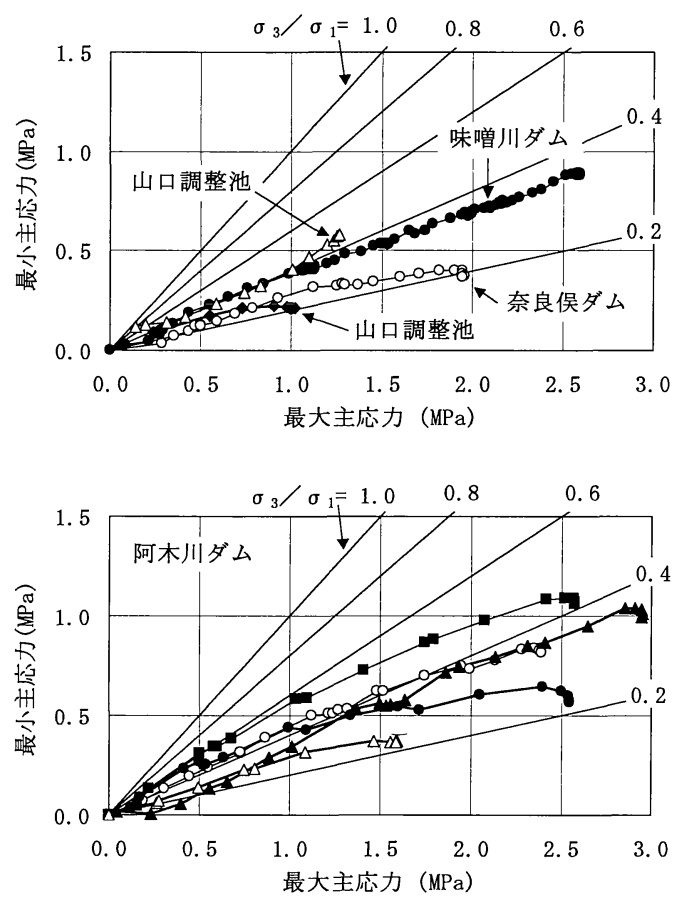

図ー7 築堤時のフィルタ部の応力経路

時期から生じていることを示している.

このように, フィルタの鉛直応力の増加傾向が顕著と なる時期が盛立初期であること, コアの鉛直応力の増加 傾向の低下が盛立後半であることから, コア部の鉛直応 力の増加傾向の低下はフィルダムの三角形の堤体形 状による影響が大きいものと推察される. 有限要素法を 用いた逐次築堤解析では, 図ー4に示すようなコア部 とフィルタ部の異なった応力経路にも着目して解析精度 の向上を図っていくことが望まれる.

\section{c) 築堤時の応力経路}

築堤時におけるコア部の最小・最大主応力の応力経 路を図ー5に示す. 3面土圧計のうち側面土圧計は誤 差が生じやすいので, 段ずれや急激な応力低下を起こ
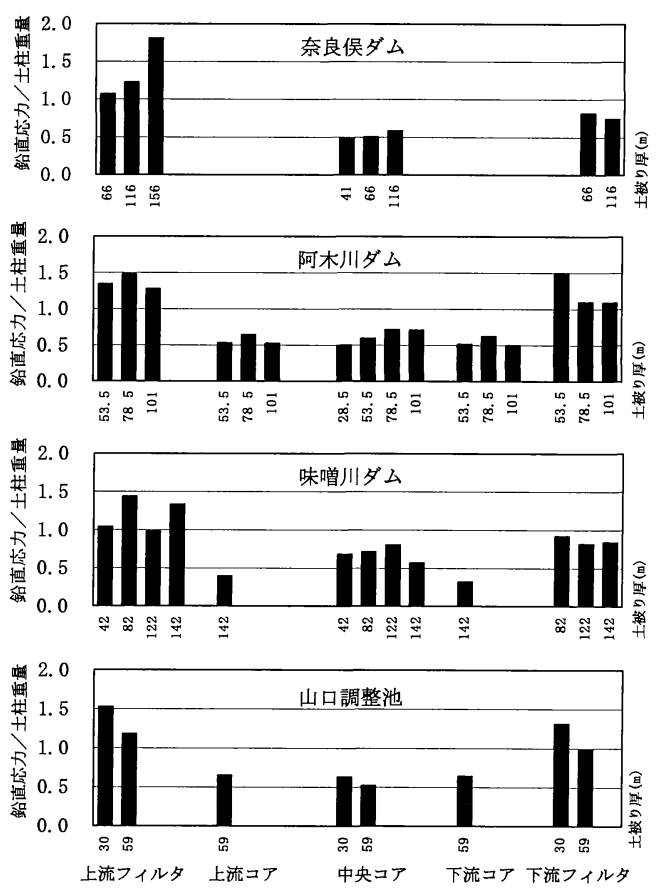

（横軸の数値：計器上部の土被り厚）

図-8 各ダムの鉛直応力／土柱重量の比較

した信頼性の低下した計測值は除外した. 縦軸が最小 主応力, 横軸が最大主応力で, 最小主応力と最大主応 力の比が $\sigma_{3} / \sigma_{1}=1.0,0.8,0.6,0.4,0.2$ となる線 を併記している. 図一5の上図に示すように各ダムのコ ア部の最小・最大応力比は $\sigma_{3} / \sigma_{1}=0.4 \sim 1.0$ 程度と ばらつきがあるが, 概ね応力比一定で応力増加してい る. 図一5の下図に示寸阿木川ダムでは各土圧計で比 較的良好な計測值を収録することができており, その応 力比はいずれも $\sigma_{3} / \sigma_{1}=0.8$ 程度の一定傾向で応力 増加している. 図ー6にロック部の応力経路を示す. 各 ダムの最小・最大主応力比は $\sigma_{3} / \sigma_{1}=0.2 \sim 0.6$ 程度 とばらつきがあるが, 概ね応力比一定で応力増加して いる. 図ー7にフィルタ部の応力経路を示す. 各ダムの 最小・最大応力比は $\sigma_{3} / \sigma_{1}=0.2 \sim 0.6$ 程度とばらつ きがあってやや低下傾向はあるものの, 概ね応力比一 定で応力増加している. この傾向は, これまでの既往の 研究成果と同様な傾向である ${ }^{8,19,201}$.

\section{(2) 築堤完了時の鉛直応力}

\section{a) 各ダムの鉛直応力／土柱重量}

各ダムにおけるフィルタ部とコア部の鉛直応力の差を 比較するために, 図一8に各ダムの鉛直応力／土柱重 量の比較を示した. 鉛直応力は底面土圧計の計測值を 用い, 土柱重量は当該土圧計の設置箇所から堤頂まで 
表ー2 築堤解析に用いた解析パラメータ

\begin{tabular}{|c|c|c|c|c|c|c|c|}
\hline & 単位 & ロックI & ロック II & ロック而 & フイルタ & $\overline{\Xi P}$ \\
\hline $\begin{array}{l}\text { 単位体積 } \\
\text { 重量 } \\
\end{array}$ & $\gamma_{t}$ & $\mathrm{kN} / \mathrm{m}^{3}$ & 19.6 & 19.6 & 19.6 & 20.6 & 20.6 \\
\hline \multirow{2}{*}{ 強度定数 } & $C$ & $M N / m^{2}$ & 0.098 & 0.078 & 0.078 & 0.078 & 069 \\
\hline & $\phi$ & & 43 & 42 & 42 & 38 & 22 \\
\hline \multirow{3}{*}{$\begin{array}{l}\text { 弾性係数 } \\
E_{t}\end{array}$} & $K$ & & 600 & 450 & 450 & 2000 & 170 \\
\hline & $\underline{n}$ & & 0.60 & 0.70 & 0.70 & 0.40 & 0.85 \\
\hline & $R_{f}$ & & 0.90 & 0.90 & 0.90 & 0.90 & 0.90 \\
\hline \multirow{3}{*}{$\begin{array}{l}\text { ポアソン } \\
\text { 比 } v_{t}\end{array}$} & $G$ & & 0.30 & 0.25 & 0.25 & 0.40 & 0.38 \\
\hline & $F$ & & 0.20 & 0.20 & 0.20 & 0.20 & 0.00 \\
\hline & $D$ & & 10 & 10 & 10 & 9 & 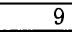 \\
\hline
\end{tabular}

Duncan らの近似式

$$
\begin{aligned}
& E_{t}=K \cdot P_{a}\left(\sigma_{3} / P_{a}\right)^{n}\left\{1-\frac{R_{f}(1-\sin \phi)\left(\sigma_{1}-\sigma_{3}\right)}{2 c \cdot \cos \phi+2 \sigma_{3} \sin \phi}\right\}^{2} \\
& v_{t}=\frac{G-F \cdot \log \left(\sigma_{3} / P_{a}\right)}{\left[1-\frac{D\left(\sigma_{1}-\sigma_{3}\right)}{K \cdot P_{a}\left(\sigma_{3} / P_{a}\right)^{n}\left\{1-\frac{R_{f}(1-\sin \phi)\left(\sigma_{1}-\sigma_{3}\right)}{2 c \cdot \cos \phi+2 \sigma_{3} \sin \phi}\right\}}\right]^{2}}
\end{aligned}
$$

の土被り厚に対して施工管理から得られた堤体の平均 単位体積重量を乗じて求め, これを縦軸に鉛直応力／ 土柱重量として示した. 各ダムでは $2 \sim 4$ 標高に土圧計 を設置し,コア部においては中央測線以外に上下流測 線にも土圧計を設置していることから，これを比較できる ように横軸に併記した。

フィルタ部の鉛直応力／土柱重量はダムによってば らつきはあるものの, 概ね土柱重量の $0.8 \sim 1.5$ 倍で, コア部は概ね土柱重量の $0.4 \sim 0.7$ 倍程度となり, フィ ルタ部とコア部の鉛直応力の比率は約 2 倍である. これ は, 他のロックフィルダムの実測值と同程度である ${ }^{2)}$. ま た, 上流側フィルタ部の土圧が下流側よりも大きくなって いる原因は, 上流側のフィルタ幅が下流側よりも小さく, 狭いフィルタ幅でロック部とコア部の荷重の一部を受け 持つことによるものと考えられる. なお，図一8には各標 高の土被り厚を併記しているが, 低土被り厚と高土被り 厚においてフィルタ部とコア部に顕著な応力差はみられ ていない.

4ダムは, ダム高が $158 \mathrm{~m} ， 140 \mathrm{~m} ， 101.5 \mathrm{~m} ， 60 \mathrm{~m}$ と 幅があって使用している材料も異なっているが，図－1 に示すように一般的な中央コア型ロックフィルダムの形 状をしている. このような規模と形状をしたロックフィルダ ムに対して,フィルタ部とコア部の鉛直応力比は平均的 に約2倍であることが示された.

\section{b) コア部の鉛直応力の低下}

フィルタ部への応力集中とコア部の応力低下の程度 を比較するために, 阿木川ダムに対して築堤時の物性

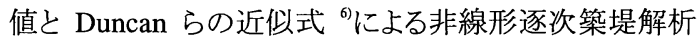
を行った. 解析では, 築堤時に計測された土圧計の鉛

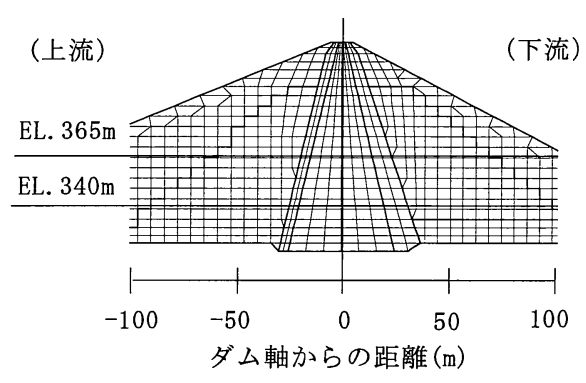

図－9阿木川ダムの解析モデル

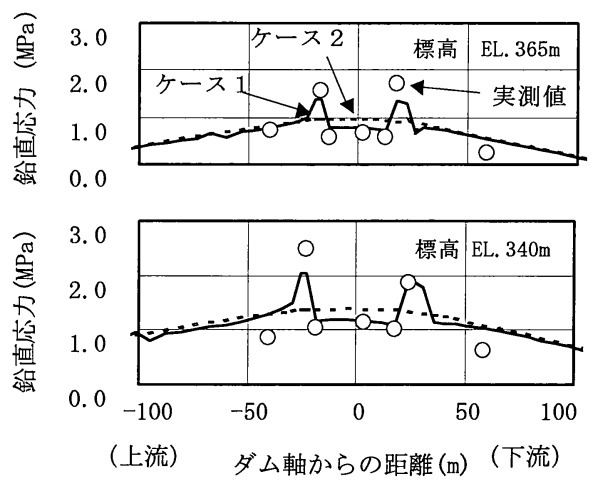

図ー10阿木川ダムにおける 鉛直応力の実測值と解析值の比較

直応力や鉛直ひずみに解析結果が適合することを優先 して, パラメータを逆解析から求めている. 解析に用い たパラメータを表ー2に示す. その解析モデルを図ー9 に示す.この図は全幅 $478 \mathrm{~m}$ 堤体全体モデルのうち, 図一10と比較しやすいようにダム軸から上下流 $100 \mathrm{~m}$ 範 囲のみ図化している. そして, 有限要素法で求めた鉛 直応力と土圧計の実測值を比較した結果を図ー10に示 す.この図は, EL.365m と 340m の鉛直応力の分布を 示したものである. 図中の○印が土圧計の鉛直応力の 実測值で, 実線のケース1がロック部, フィルタ部ならび にコア部の物性值をもとに逐次築堤解析して求めた鉛 直応力である. フィルタ部で鉛直応力が高く, コア部で 低下する実測值と概ね整合する結果となっている.これ は,フィルタ部の剛性がコア部やロック部よりも大きいこ とによるものである. 次に, フィルタ部への応力集中が生 じないように, フィルタ部およびロック部の物性值をコア 部と同じ物性值で解析した. その結果を図ー10に破線 のケース2として示寸が, 当然のことながらフィルタ部へ の応力集中は発生せず, コア部の鉛直応力が大きくな っている. ケース1とケース 2 を比較すると, コア部で鉛 直応力に約 $1 \sim 2$ 割の差が生じている. 実測值はほぼケ 

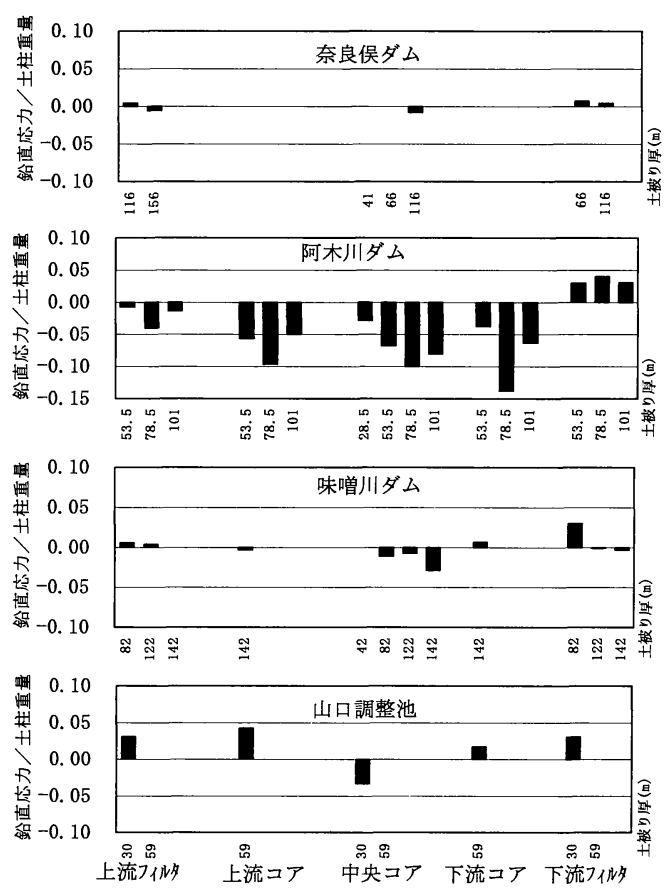

（横軸の数值：計器上部の土被厚）

（築堤完了時を 0 基準とした湛水開始までの増減）

図-11 放置期間中の鉛直応力／土柱重量の変化

一ス1の解析值に近い值が得られていることから,フィル 夕部の応力集中によって, コア部の鉛直応力が約 $1 \sim 2$ 割程度低下していることが推定される.

従来からフィルタ部ならびにコア部の応力差が指摘さ れてきたが, 本検討で取りあげた4ダムにおいても, 盛 立とともにフィルタ部に応力集中する傾向が確認され, コア部とフィルタ部との鉛直応力の差は約 2 倍程度ある ことがわかった. しかし, コア部の応力低下については, 土被り厚と応力経路からみて堤頂付近の盛土荷重の低 減に伴う応力低下の影響が大きく, 阿木川ダムではフィ ルタ部への応力集中が無い場合のコア部鉛直応力に 対して, 約 1 ～2割程度の応力低下を生じていることを 示した.

このように, ロックフィルダムは, 築堤時でフィルタ部 への応力集中はするものの, コア部の応力低下は約 1 〜2割で, 最小・最大主応力比が一定で増加することか ら, 築堤時や築堤完了時の堤体内応力状態は安定し たものと考えられる. なお, コア部の応力低下に対して, これを小さくするようなロックフィルダムの研究課題への 展開も望まれる.

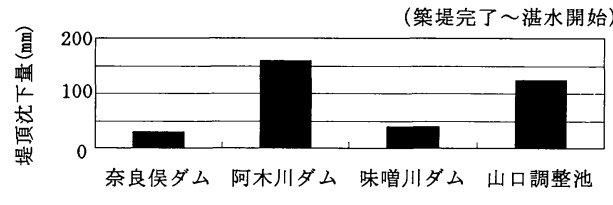

図-12 放置期間中の堤頂の沈下量

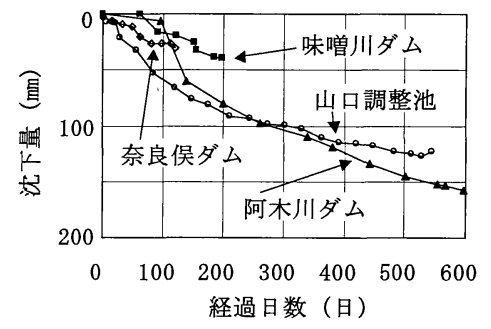

図-13 放置期間中の堤頂沈下量の経時変化

\section{(3) 放置期間中の鉛直応力の変化}

先に示した図ー 3 の阿木川ダムでは, 築堤完了後に 時間の経過とともにコアの鉛直応力が低下寸る傾向が みられる. よって, 各ダムにおける放置期間中の応力変 化を比較するために, 図一11に各ダムにおける築堤完 了後から湛水開始までの鉛直応力の変化を示した. 縦 軸はフィルタ部とコア部の鉛直応力／土柱重量を示し, 築堤完了時点を 0 基準とした湛水開始までの放置期間 中の応力増減を表している. 横軸は, 図-8 と同様に 各ゾーン部と設置箇所上部の土被り厚で分けて示して いる.

コア部の鉛直応力は全体的に各ダムとも低下する傾 向を示し，阿木川ダムの鉛直応力の低下が顕著であ る. 放置期間中は築堤時と比較して応力の変化量が小 さいために明確な傾向は示せないが, 全体的傾向とし てコア部の鉛直応力が低下し, フィルタ部が増加する傾 向を示している. 次に, 図一12に築堤完了時を 0 基準と した湛水開始までの放置期間中の堤頂の沈下量と図一 13にその経時変化を示す. 阿木川ダムと山口調整池は 放置期間が長いために圧密沈下量が大きい傾向を示 している.フィルタ部は材料の粒度分布がよいことから 推定されるように変形係数が大きい材料である.これに 対してコア部は土質材料で, 圧密沈下寸る.このコア部 とフィルタ部が接していることから, コア部が沈下しようと した場合にフィルタ部がこれを抑制することが考えられ る. コア部の沈下に対するフィルタ部の沈下抑制作用の 結果として, フィルタ部にコア部の応力の一部が転化さ れ, フィルタ部の応力が増加してコア部の応力が低下 することがあると推定される. 堤頂の沈下量が大きい阿 木川ダムにおいてコア部の鉛直応力の低下が大きいの 


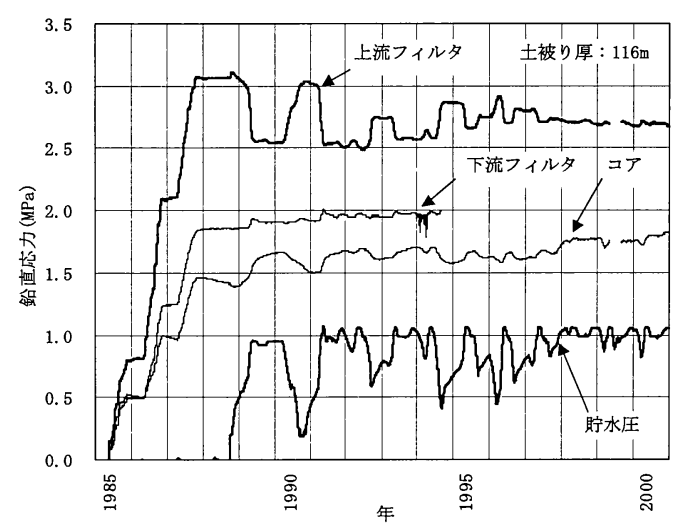

図-14 奈良俣ダムの鉛直応力の経時変化

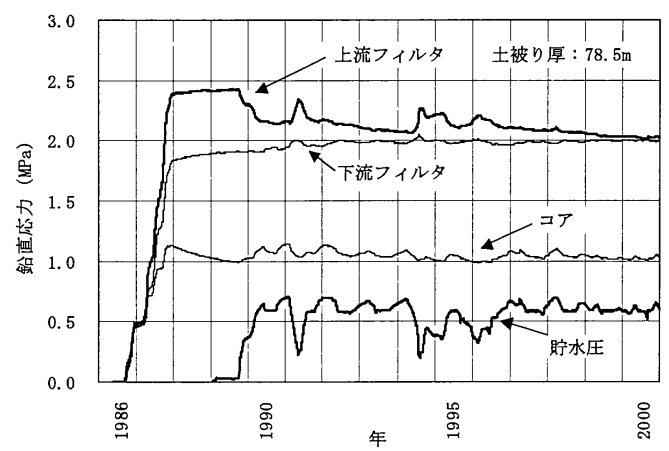

図-15 阿木川ダムの鉛直応力の経時変化

は,この要因が大きいためと思われる. なお, 阿木川ダ ムの上流フィルタ部の鉛直応力／土柱重量が低下傾向 を示していること, 他ダムでも鉛直応力／土柱重量にば らつきがあることについては, 放置期閒中は全体的に応 力変化量が小さく計測誤差を含むためと考えられる.

従来, 築堤完了時点の堤体の安定性は, 築堤完了 時の応力状態をもとに評価することが多い. しかし, 築 堤後の放置期間中も, コア部の圧密沈下にともなってフ イルタ部への応力集中とコア部の応力低下の傾向がみ られる. 築堤完了後のコア部の沈下量が比較的大きい ダムについては, 放置期閒中の鉛直応力の変化にも留 意する必要があると考えられる.

\section{(4) 湛水時の鉛直応力の変化}

フィルダムの応力変化は大きく築堤時の応力増加時 と湛水に伴う応力変化に分けられる. 築堤時は図ー8に 示すようにフィルタ部に応力集中する傾向を確認してい る. 次に, 湛水に伴って上流ロック部ならびに上流フィ ルタ部に浮力が作用し, 堤体の応力分布が変化する. 特に築堤時に応力集中したフィルタ部と応力低下した コア部に対して, 湛水による応力変化を図 - 14, 15,

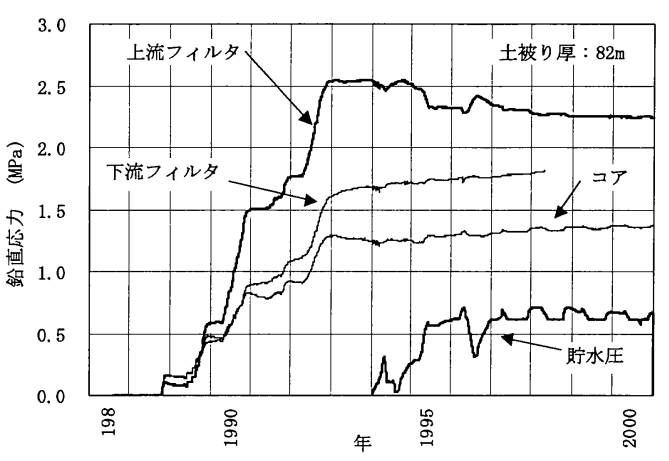

図-16 味増川ダムの鉛直応力の経時変化

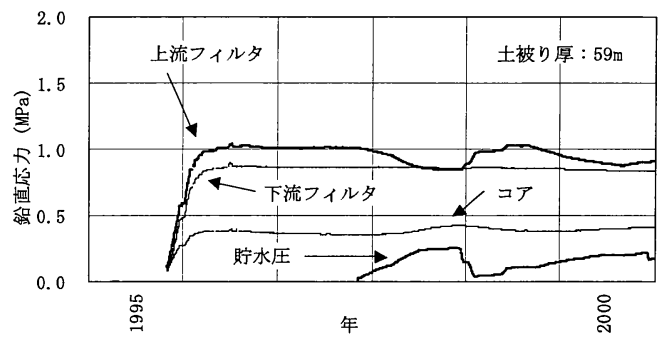

図-17 山口調整池の鉛直応力の経時変化

16,17に比較した.この図は, 4ダムの築堤時ならびに 湛水時における長期的な鉛直応力の変化を示してい る. 鉛直応力は底面土圧計の計測值で, 4 ダムの土被り 厚が同じ程度となるように中標高の土圧計計測值とし た. なお, 山口調整池は堤高が $60 \mathrm{~m}$ と低いために堤体 基礎部の土圧計としている. そして, 同一標高のフィル タ部とコア部の鉛直応力のほかに, 土圧計設置標高に おける換算貯水圧も併記した. この換算貯水圧とは, 当 該日の貯水位から土圧計設置標高を差し引いて貯水 圧に換算したものである.

各ダムの上流フィルタ部の鉛直応力は, 全体的に湛 水後の貯水位上昇とともに逆に低下寸る傾向を示して いる. 計測值が全応力であることから, 本来湛水によっ て堤体が飽和して上流フィルタ部の鉛直応力は増加す ベきところであるが, 逆に低下している. また，上流フィ ルタ部の鉛直応力は, 初期湛水以降も貯水位の変動に 連動して増減しているが, その変動割合は小さくなる傾 向を示している. 図－18に, 4ダムの上下流フィルタ部と コア部における試験湛水開始時と試験湛水時の第1回 最高水位時における鉛直応力／土柱重量の比較を示 す.この図は図－8と同様に上下流フィルタ部とコア部 における各土被り厚の土圧計の計測值を横軸に示して いる. なお, 試験湛水開始時には計測されていて第1回 

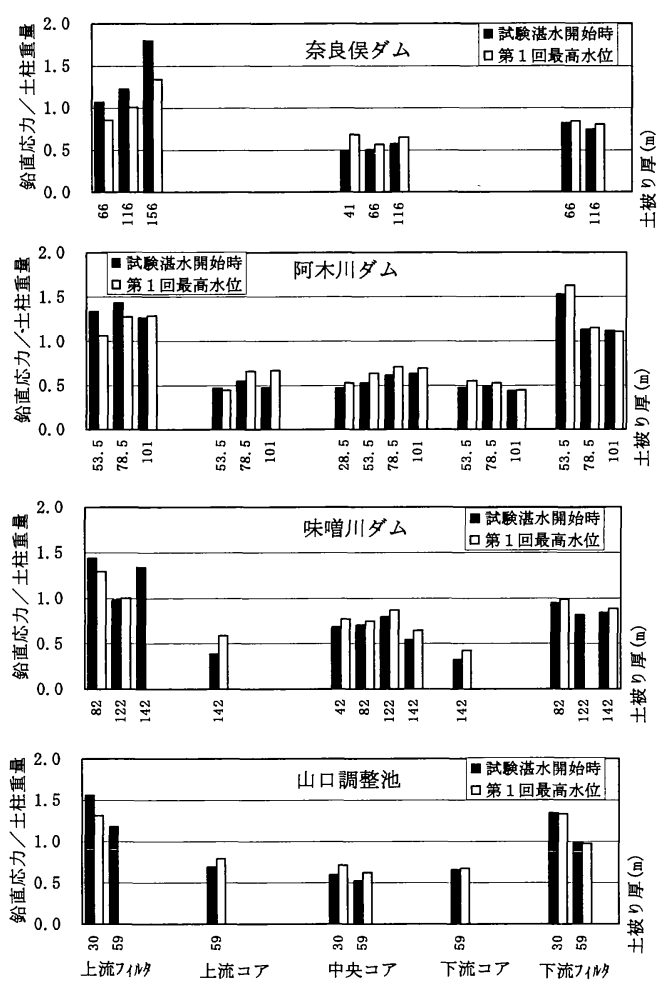

(横軸の数值：計器上部の土被り厚）

図-18 湛水に伴う鉛直応力／土柱重量の変化

最高水位時に欠測した土圧計計測值は, 試験湛水開 始時の計測值のみ記載した. 上流フィルタ部の鉛直応 力は, 全体的に試験湛水開始時に対して第 1 回最高水 位時で低下する傾向を示している. この鉛直応力の低 下程度はダムによってばらつきがあり,フィルタ部への 応力集中度合や個々の土圧計の測定精度などが影響 しているものと考えられる. なお, 阿木川ダムの土被り厚 $101 \mathrm{~m}$ と味噌川ダムの土被り厚 $122 \mathrm{~m}$ における上流フィ ルタ部の鉛直応力は湛水してもほとんど変化せず, 堤 体中段標高の応力低下とは異なる傾向を示した.この 応力変化が小さい土圧計の鉛直応力は, 他標高の鉛 直応力／土柱重量よりも小さく, 試験湛水開始時で応 力集中が小さいものである.

貯水位の上昇とともに上流フィルタ部の鉛直応力が 低下寸る要因の一つとして, 湛水に伴って上流ロック部 に浮力が作用し，上流フィルタ部への応力集中が緩和 され，上流フィルタ部の鉛直応力が低下することが考え られる. 図ー19に阿木川ダムにおける上流ロック部およ び上流フィルタ部における土圧計の鉛直応力と貯水圧 の関係を示す.この土圧計は図ー2に示す EL. $340 \mathrm{~m}$ と EL. $365 \mathrm{~m}$ の計測值である. 上流ロック部の有効応力
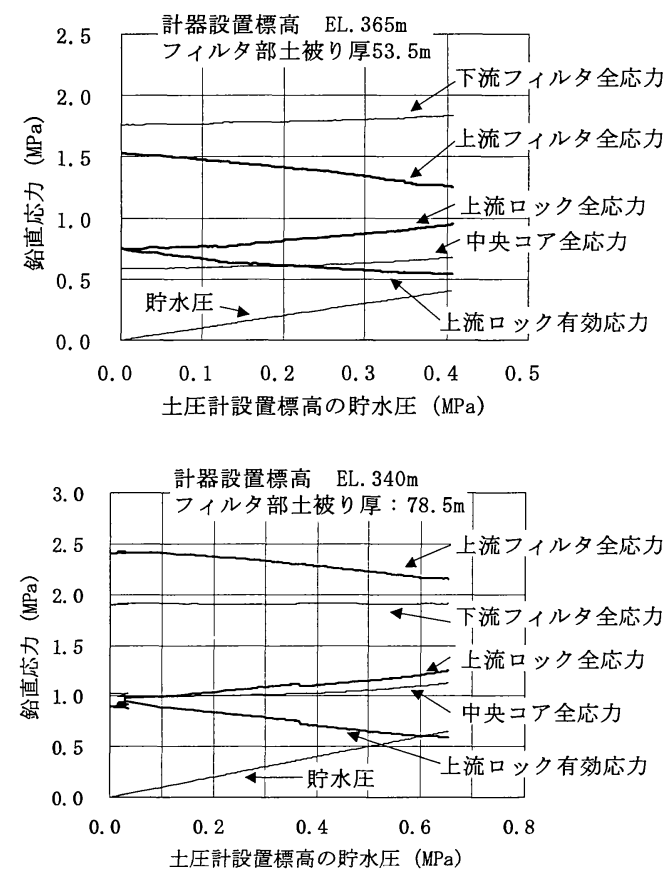

図-19 阿木川ダムにおける鉛直応力と貯水圧

は, 全応力から貯水圧を間隙水圧と見なして差し引い たものである. 参考にコア中央部と下流フィルタ部の鉛 直応力も併記する. 両標高とも, 湛水前は上流ロック部 の応力の一部がフィルタ部に作用していたが, 貯水圧 の上昇とともに上流ロック部の有効応力が低下し，これ に伴ってフィルタ部へ作用していたロック部の応力が低 下して,フィルタ部の全応力が低下したことが推察され る. なお，貯水圧の増加とともに中央コア部の鉛直応力 が増加し， EL.365m の下流フィルタ部では鉛直応力が 若干増加する傾向を示している.この要因として, 貯水 位の上昇とともにコア部に貯水圧が作用してコア部の鉛 直応力が増加するとともに, 堤体変形によって下流フィ ル夕部の鉛直応力が若干増加したことが推察される.し かし，この貯水圧の作用だけで上流側フィルタ部の鉛 直応力が大きく低下することは考えにくい. また, 上流〉 イルタ部の鉛直応力は, 試験湛水開始時から第1回最 高水位時で大きく低下するものとほとんど変化しないも のに分けられるが，試験湛水開始時に応力集中によっ て鉛直応力が大きい土圧計の方が第 1 回最高水位時 に低下寸る傾向が多い.このようなことから推察すると, 上流フィルタ部の鉛直応力 (全応力)が貯水位の上昇と ともに低下する主要因として, 上流ロック部の有効応力 の低下によって応力集中した上流フィルタ部の鉛直応 力が低下することが考えられ，一部下流への堤体変形 による影響も含まれると思われる. 


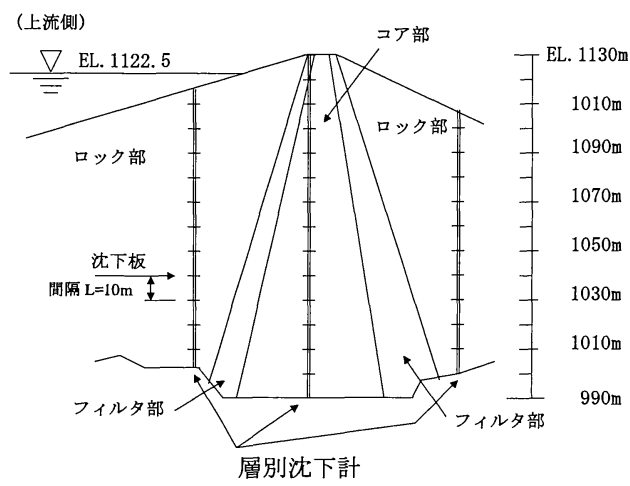

図-20味増川ダムの層別沈下計配置図

コア部の鉛直応力／土柱重量の比較を図ー18でみ ると，第1回最高水位時の方がやや大きくなっている. 貯水位上昇に伴う貯水圧の作用や堤体の不飽和から 飽和状態への移行などの影響によって, コア部の鉛直 応力はやや増加する傾向を示したと考えられる.

下流フィルタ部の鉛直応力／土柱重量の比較を図 -18でみると,ほとんど変化しないかもしくは第1回最高 水位時の方が若干増加する傾向を示した. 下流フィル 夕部で間隙水圧が発生していないことや上流側に傾斜 していることを考慮すると, 貯水圧の直接の作用ではな く, 堤体変形の影響によって鉛直応力が若干増加した と推察される.

湛水時の応力状態は, 貯水位の上昇とともに上流つ イルタ部の応力集中が緩和され，堤体の安全性に寄与 されることから，これを再現できるように湛水解析の向上 を図っていくことが望まれる.

\section{5. 堤体のひずみ挙動}

築堤時に発生する堤体のひずみ分布はダムによって かなりばらつきがある ${ }^{2}$.このため, 堤体内に層別沈下 計を設置し, 筑堤時や築堤完了後の堤体のひずみ分 布を把握している. 図一20に味噌川ダムにおける層別 沈下計の配置図を示す.コア部と上下流ロック部に層 別沈下計が設置されている. この層別沈下計は盛立 $10 \mathrm{~m}$ 毎に沈下板を設置し, 堤体内の沈下量を計測して いる. この層別沈下計の各沈下板の鉛直変位量の相対 差功求めた圧縮量 $(\mathrm{dL})$ と測点間隔長 $(\mathrm{L})$ 加鉛直ひ ずみを求めることができる. よって, 層別沈下計が設置 されているコア部ならびに上下流ロック部の鉛直ひずみ の発生状況を検討することとした。

コア部の鉛直ひずみ分布を図ー21に, 上下流ロック 部の鉛直ひずみ分布を図ー22に示す. 縦軸は, 層別

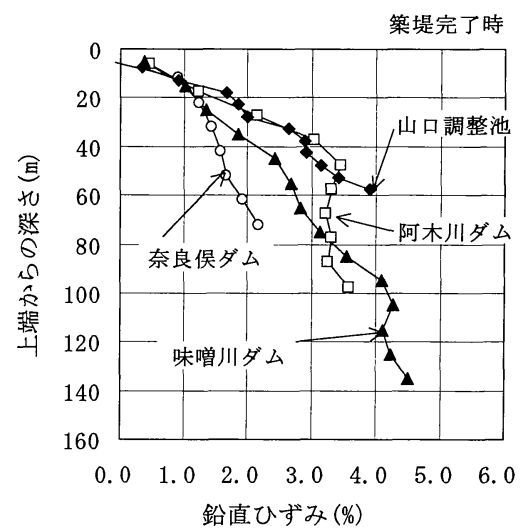

図－21＼cjkstart層別沈下計によるコア部の鉛直ひずみ

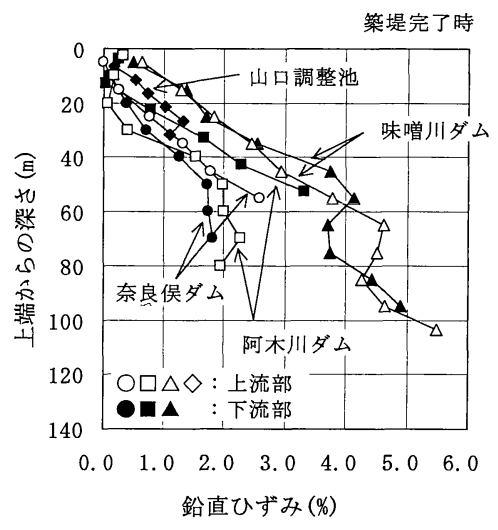

図－22 層別沈下計によるロック部の鉛直ひずみ

沈下計の上端からの深さを, 横軸は鉛直ひずみを示し ている. なお, 沈下板の沈下量のうち1箇所の值が計測 誤差等によって変動するとその上下の鉛直ひずみが大 きく変化することから, 久納 ${ }^{211}$ が行った4測点間を平均 する方法を用いて鉛直ひずみの誤差を小さくした. コア 部の鉛直ひずみは, 深さ方向に対して大きくなる傾向を 示す.ささらに, 鉛直ひずみの増加傾向は浅部で大きく, 深部で低下する傾向を示している. ロック部の鉛直ひず みは, 深さ方向に対して直線的に大きくなるダムと, コア 部と同様に深部で増加傾向が低下するものがある.こ の鉛直ひずみと堤体表面からの染さとの関係は概ね次 式で表現される． $\alpha$ は堤体表面からの深さに対する鉛 直ひずみの増加割合を表すものである.

$$
\varepsilon v=\alpha \times h
$$

ここに,

$\varepsilon \mathrm{v}:$ 深さ方向の鉛直ひずみ $(\%)$

$h:$ 堤体表面加の深さ $(\mathrm{m})$ 

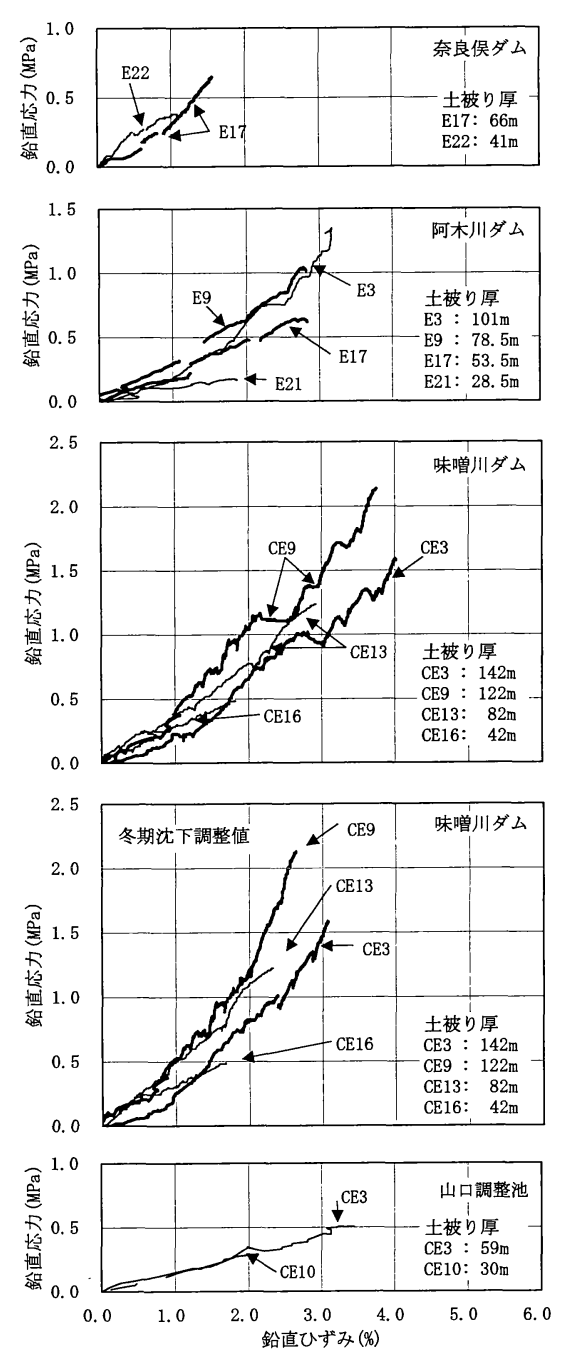

図一23 各ダムのコア部の鉛直ひずみ〜鉛直応力

$$
\begin{gathered}
\alpha: \text { コア }(0.03 \sim 0.09) \\
\text { ロック }(0.03 \sim 0.08)
\end{gathered}
$$

この関係は, 坂本ら ${ }^{2)}$ が最終盛立標高と最大鉛直ひ ずみでまとめた相関関係と概ね整合するもので, 堤体 材料によって鉛直ひずみの分布はかなりばらつきがあ ることを示している.

4ダムのうち特に味噌川ダムのロック部の鉛直ひずみ については, 図ー22に示すように深さ $60 \mathrm{~m}$ 以深で鉛直 ひずみが一旦低下する傾向を示し, 深部でまた増加し ている.このことは, 堤体の上部, 中段部ならびに深部 において盛立段階の堤体の鉛直ひずみの増加傾向す なわち変形係数が顕著に異なる可能性を示している.
これについては, 次節で詳述する.

\section{6. 堤体の応力・ひずみ挙動}

\section{(1)コア部の応カ・ひずみ挙動}

堤体内には築堤時の応力ひずみ経路を把握するた めに層別沈下計の近くに土圧計を設置している. 本検 討では, 4ダムについてコア内の層別沈下計沿いに設 置している土圧計の鉛直応力と層別沈下計から求めた 鉛直ひずみから, 鉛直ひずみと鉛直応力の関係を整理 した. 築堤時の鉛直ひずみと鉛直応力の関係を図 -23 に示す. 図には土圧計上部の土被り厚も併記した. 以 下に，実測された鉛直応力と鉛直ひずみから求めた見 かけの変形係数の特徴を示す.

奈良俣ダムでは層別沈下計の下部の計器が測定不 能となったために中段から上部の土圧計の值を標記し ている. 奈良俣ダムの E17 の見かけの変形係数は, 鉛 直応力が小さい時期で約 $30 \mathrm{MPa}$ ，鉛直応力が大きくな ると約 $60 \mathrm{MPa}$ 程度に増加している. また, E22 の見か けの変形係数は平均的に $40 \mathrm{MPa}$ 程度である.

阿木川ダムにおける堤体下部の E3 と E9 の見かけ の変形係数は, 鉛直応力 $0.5 \mathrm{MPa}$ 以下では約 $20 \sim$ $30 \mathrm{MPa}$ で, 鉛直応力が大きくなると約 $50 \sim 60 \mathrm{MPa}$ に 増加している. また, 堤体上部の E17 と E21 の見かけ の変形係数は, 鉛直応力と鉛直ひずみの関係が直線 的で, すなわち見かけの変形係数が一定の傾向を示 し, E17 が約 25MPa，特に E21 が約 10MPa と小さくな っている.

味噌川ダムでは, 積雪のために冬期盛立が休止され たことから, 冬期間に圧密が進行して鉛直ひずみが増 加している. よって, 図一23には, 鉛直ひずみの実測值 と, 冬期間の圧密沈下による鉛直ひずみの増分を除外 した冬期沈下調整值を併記した. 以下, 冬期沈下調整 值で見かけの変形係数を比較する. CE3 と CE16 の見 かけの変形係数は, 鉛直応力が $0.5 \mathrm{MPa}$ 以下では約 $30 \mathrm{MPa}$ と小さい. CE3 は他の土圧計と比較して鉛直応 力の発生が低めの傾向を示しており, 土圧計の計測值 の信頼性が落ちている可能性がある. また, CE9 と CE13 は見かけの変形係数は約 $50 \mathrm{MPa}$ と大きい. そし て, CE3，CE9 および CE13 の見かけの変形係数は, 鉛直応力が大きくなると増加する傾向を示し, 鉛直応力 が $1 \mathrm{MPa}$ を越えると見かけの変形倸数は約 100 〜 $150 \mathrm{MPa}$ となっている. なお, 堤体上部の CE16 の応力 ひずみの関係は直線的で, 見かけの変形係数は 30MPa と小さいままである.

山口調整池の応力ひずみの傾向は, 堤体底部の $\mathrm{CE} 3$ と中段部の $\mathrm{CE} 10$ とも直線的で, 見かけの変形係 


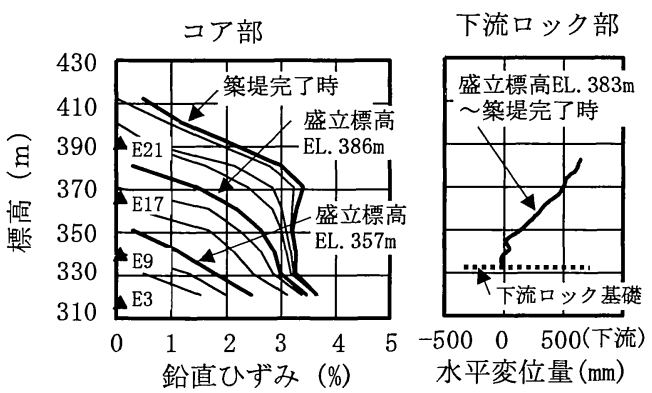

図-24阿木川ダム築堤時のコア部鉛直ひずみ および下流ロック部の水平変位の増加傾向

数は $15 \mathrm{MPa}$ と他ダムと比較して小さい.

築堤時の応力ひずみの全体的な傾向として, 鉛直応 力が小さい $0.5 \mathrm{MPa}$ 程度までは, 見かけの変形係数は $10 \sim 50 \mathrm{MPa}$ と小さいが, それ以降は約 $40 \sim 80 \mathrm{MPa}$ と増加し, 休止期間の圧密沈下を除けばさらに大きくな る傾向を示している. そして, 堤体上部の応力ひずみ は, 鉛直応力がまだ小さいこともあるが, 見かけの変形 係数は一定傾向を示している. 特に阿木川ダムの堤体 上部の E21 は見かけの変形係数が約 $10 \mathrm{MPa}$ と小さく, 下部の E3, E9, E17 の見かけの変形係数と大きく傾 向が異なる特徴を示した.

阿木川ダムについて, コア部の標高毎に築堤時の鉛 直ひずみの増加傾向を図－24の左図に示した. 図は縦 軸に盛立標高を横軸に鉛直ひずみを示し, 各盛立途 中の鉛直ひずみの増加傾向がわかるように盛立約 $10 \mathrm{~m}$ 毎の鉛直ひずみを示している. 標高約 EL.370m 以上 において鉛直ひずみの増加傾向が大きくなっている. 図ー23で示した阿木川ダムの E21 の応力ひずみの傾 向は, 図-24の EL.390m 付近の鉛直ひずみの増加傾 向に該当する. 阿木川ダムには, 下流ロック部の層別沈 下計に傾斜計が組み込まれている.この傾斜計におい て盛立標高 EL.383m から築堤完了時までの上下流方 向の水平変位が測定されている.これを図一24の右図 に示す. 標高約 EL. 350m よりも上部で急激に下流側に 水平変位量が増加している. 堤体上部は三角形状をし てロック部の上下流方向の堤敷幅が短く, 上下流方向 に変位しやすい構造で, 佐藤ら ${ }^{11}$ はロック部の盛立段 階の側方変位を示している. ロック部の上下流方向へ の変位に伴ってコア部の水平ひずみが大きくなって鉛 直ひずみの増加傾向が低下せず, コア部上部の応力 ひずみが直線的で見かけの変形係数が小さいままとな った可能性が考えられる.コア部上部の見かけの変形 係数が増加しない傾向は奈良俣ダムの E22 や味噌川 ダムの CE16 でもみられる.なお, 山口調整池では, ダ

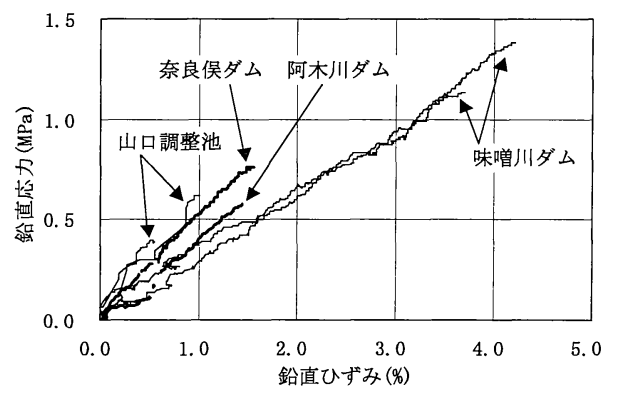

図-25 各ダムロック部の鉛直ひずみ〜鉛直応力
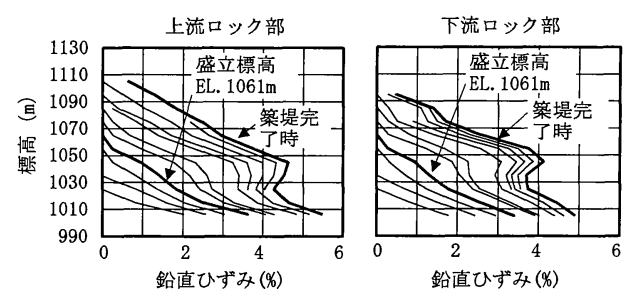

図-26 味噌川ダム築堤時のロック部の 鉛直ひずみの増加傾向

厶高が低くて鉛直応力が 3 ダムの堤体上部と同程度し かないことから,コア部上部と底部の双方が見かけの変 形係数一定の傾向を示したと考えられる.

以上のとおり,コア部で実測された鉛直応力と鉛直ひ ずみから求めた見かけの変形係数は, 鉛直応力約 $0.5 \mathrm{MPa}$ 以下では $10 \sim 30 \mathrm{MPa}$ と小さいが, それ以降 では約 $40 \sim 80 \mathrm{MPa}$ と増加し, 休止期閒の圧密沈下を 除けばさらに大きくなる傾向を示した. 岩片 ${ }^{22}$ がコア部 の応力ひずみの傾向を標高に関係なく全体的な傾向 で非線形挙動として示していたのに対して, 本検討では 堤体下部の応力ひずみは非線形な挙動を示すが, 堤 体上部は線形的で見かけの変形係数も小さく, 堤体形 状の影響の可能性があることを示した. なお,一般の三 軸圧縮試験から得られる変形係数が側圧を一定にした 試験結果であるのに対して, 堤体の実測值から得られ た見かけの変形係数は最小・最大主応力比一定の条 件下で得られたもので, 条件が異なるものである.これ らの知見は, 逐次盛土による築堤解析の評価や, 解析 技術の高度化に対して重要な指標となるものである.

\section{(2) ロック部の応カ・ひずみの挙動}

最近注目されているコンクリート表面遮水型ロックフィ ルダムでは, ロック部の変形性評価が重要であることか ら,ここではロック部の築堤時の応力ひずみの関係を検 討した. 

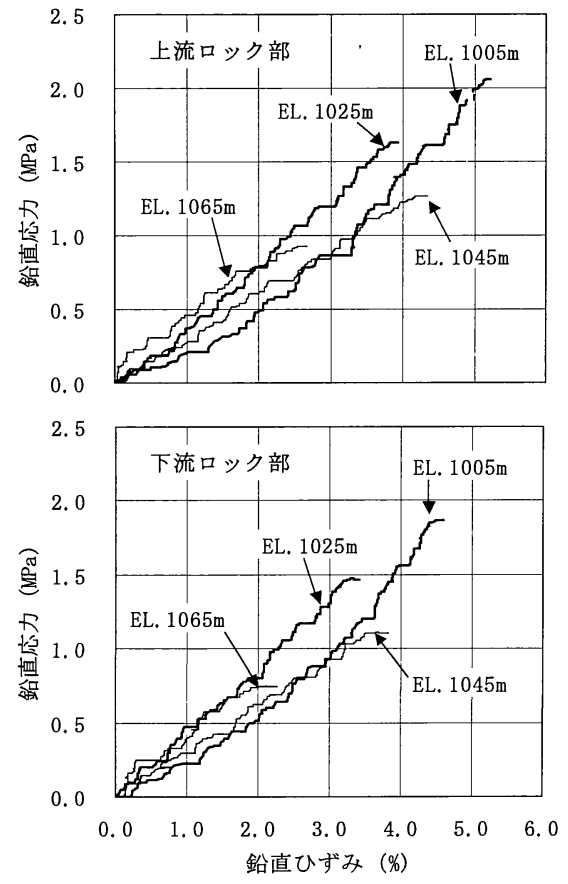

図－27味噌川ダムにおけるロック部の 鉛直ひずみ〜鉛直応力

ロック部の築堤時の鉛直応力と鉛直ひずみの関係を 図一25に示す. 対象とした土圧計は, 層別沈下計の近 くに位置するものを対象とした. ロック部の土圧計は, 口 ック材の粒径との関係で精度が劣るものがあり, 土圧計 上部の土被り厚による土柱重量に対して, 土圧計の鉛 直応力が2割以上増减しているものは除外した. また, 奈良俣ダムの土圧計はコア部と同様の理由で上部標高 のみである. 以下に, ロック部で実測された鉛直応力と 鉛直ひずみから求めた見かけの変形係数の特徴を示 す.

各ダムの応力ひずみの増加傾向は直線的で, 見か けの変形係数は奈良俣ダムで約 $50 \mathrm{MPa}$, 阿木川ダム で約 $40 \mathrm{MPa}$, 味噌川ダムで約 $30 \mathrm{MPa}$, 山口調整池で 約 $60 \mathrm{MPa}$ と, ダムによって差がある. コア部の応力ひず みの関係が鉛直応力の小さい時期と大きい時期で見か けの変形係数が異なるのに対して, ロック部は概ね一定 傾向の特徵を示した. また, 鉛直応力の約 $1 \mathrm{MPa}$ 以上 ではロック部の見かけの変形係数は $30 \sim 60 \mathrm{MPa}$ でコ ア部の $50 \sim 80 \mathrm{MPa}$ より小さく, ロック部の方が高圧縮 応力下で変形しやすい特徴を示した.

味噌川ダムでは, 図一22に示すように鉛直ひずみの 大きさが上端からの深さで逆転する箇所がある. そこ で, 図ー24と同样に, 味噌川ダムの上下流ロック部にお ける築堤時の鉛直ひずみの増加傾向を図ー26に示し

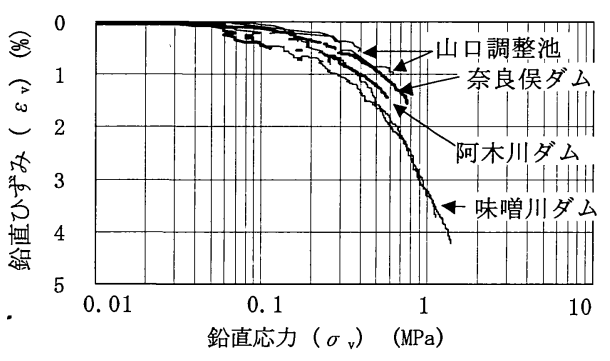

図ー28 各ダムのロック部の $\log (\sigma v) \sim \varepsilon v$
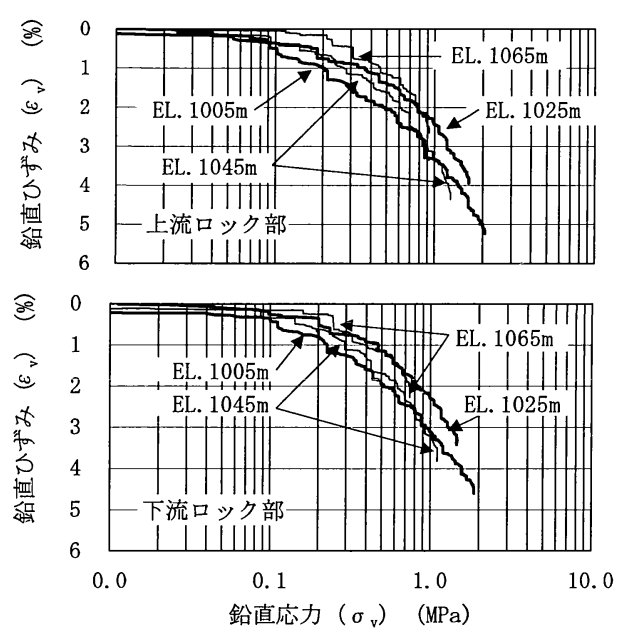

図－29 味噌川ダムにおけるロック部の $\log (\sigma$ 、 $) \sim \varepsilon$ 、

た. 図には盛立高約 $10 \mathrm{~m}$ 毎の鉛直ひずみの増加傾向 を示している.上下流ロック部では盛立標高が約 EL.1060m を越えると, 堤体内の鉛直ひずみの増加傾 向が EL.1030 1060m 付近で大きくなっている. また, 最下部の鉛直ひずみの増加傾向は盛立初期から大き い傾向を示している.

次に, 図一27に各標高における鉛直ひずみと鉛直応 力の増加傾向を比較した. 土圧計は, 層別沈下計の測 線で深度方向に2箇所しか設置しておらず, 図一27に 示す鉛直ひずみの代表点となる標高には EL.1005m を 除いて設置されていない. よって, 層別沈下計の各標 高の鉛直ひずみに対応する鉛直応力は, Duncan らの 近似式 ${ }^{6}$ による非線形逐次築堤解析から各土被り厚に 応じた鉛直応力を求めた. 縦軸は解析から求めた鉛直 忘力で, 横軸は層別沈下計から求めた鉛直ひずみであ る.

図ー27に示すように, 上下流ロック部とも EL.1005m と EL.1045m の見かけの変形係数は, 鉛直応力 $0.5 \mathrm{MPa}$ 以下では約 $20 \sim 30 \mathrm{MPa}$ と小さく, EL.1025m 
と EL.1065m は約 40MPa と大きい. また, 上下流ロック 部とも, EL.1005m 以外は応力ひずみの関係は直線的 であるが, 底部の EL.1005m の見かけの変形係数は鉛 直応力 $0.5 \mathrm{MPa}$ 以下では約 $20 \sim 30 \mathrm{MPa}$ と小さく, $1 \mathrm{MPa}$ 以上では約 $50 \sim 60 \mathrm{MPa}$ に大きくなり, コア部と 似た傾向を示している.

図一23と図－25の比較からわかるように, コア部の見 かけの変形係数は鉛直応力の増加とともに大きくなる傾 向を示すのに対して, ロック部は一定の傾向を示してい る.この要因の一つとして, コア部は堤体中央に位置 し,フィルタ部, ロック部に側方を拘束されて側方変位し にくいのに対し, ロック部は佐藤ら ${ }^{11} か ゙$ 示すように築堤 時に側方変位していることがあげられる. ロック部で実 測された鉛直ひずみは, 盛立時に発生する側方変位に 伴って増加傾向が低下せず, 見かけの変形係数が一 定になることが推定される. また，味噌川ダムの上下流 ロック部 EL.1005m の応力ひずみの傾向は, 図一20と 図－27に示すように該当箇所が土被り厚約 $100 \mathrm{~m}$ の底 部に位置するために側方変位しにくく,コア部と似た傾 向を示した可能性が推定される.

三浦ら ${ }^{23}$ は, 密に締め固められた粘性土と同様に, 締め固められた粗粒材料は弾塑性的な変形挙動となる 等価な先行圧縮応力的な考え方が成立するかについ て重要な示唆を与えている. また, 森ら "は, 大型重機 によって現場転圧された粗粒材料が高圧縮応力下で弾 塑性的な圧縮変形挙動を示すことを報告している. よっ て, 図一25に示した鉛直応力ならびに鉛直ひずみの関 係を $\log \left(\sigma_{v}\right)$ と鉛直ひずみ $\left(\varepsilon_{v}\right)$ の関係で図一28に示し た. 各ダムとも低応力領域では弾性的な挙動を示し, 高 応力領域で塑性的な挙動に推移している.このデータ から推察すると等価な先行圧縮応力は $0.2 \sim 0.5 \mathrm{MPa}$ 付近にみられる.これは, 森ら ”が実ダムから推定した 等価な先行圧縮応力と同程度である. また, 図一27で 示した鉛直ひずみと鉛直応力の関係を $\log (\sigma v)$ と鉛直 ひずみ $(\varepsilon v)$ の関係で表すと図ー29のとおりである. 上 下流ロック部とも, 底部の EL.1005m の等価な先行圧縮 応力は他の標高の等価な先行圧縮応力よりも小さい傾 向を示した.

このように, ロック部で実測された鉛直応力と鉛直ひ ずみから求めた見かけの変形係数は堤体材料によって 約 $30 \sim 60 \mathrm{MPa}$ の差はあるものの一定の傾向を示し, 鉛直応力約 $1 \mathrm{MPa}$ 以上ではロック部はコア部より見かけ の変形係数が小さく, 高圧縮応力下では変形しやすい 特徵を示した. そして, 味増川ダムの底部ロック部の応 カひずみの傾向はコア部に類似した傾向を示し, 堤体 形状の影響の可能性が推察された. さらに, ロック部の 応力ひずみの関係を $\log \left(\sigma_{v}\right) \sim \varepsilon_{\mathrm{v}}$ の関係でみると, 等 価な先行圧縮応力が $0.2 \sim 0.5 \mathrm{MPa}$ 付近にみられた.
これらの知見は, 今後のコンクリート表面遮水壁型ロック フィルダムの設計に当たって, ロック部の変形特性を評 価する上で重要な知見となるものである.

\section{7. おわりに}

水資源機構の $4 つ$ッックフィルダムについて, 築堤 および湛水時の実測応力ひずみ挙動を検討した. 得ら れた結果を表ー 3 にまとめた.

中央土質遮水壁型ロックフィルダムの場合, フィルタ 部への応力集中に伴ってコア部の応力低下が $1 \sim 2$ 割程度生じていることがわかった. 湛水時の堤体の安 全性向上に関する研究課題として, コア部の応力低下 を極力小さくするようなロックフィルダムの研究がある. 例えば，以前よく採用されていた傾斜土質遮水壁型ロッ クフィルダムのようにコア部に上流側ロック部の荷重が 大きく作用するようなゾーン型式の研究などがあり, 再 検討していくことが望まれる. 今後は本検討で得られた フィルタ部およびコア部の応力分布に対して, コアの応 力低下を小さくする取り組みを進めていく必要がある.

また, 地震時の堤体安全性評価として重要となる地 震前の応力状態については, 堤体の低標高から高標 高までフィルタ部への応力集中とコア部の応力低下が 生じていること, 湛水時は上流フィルタへの応力集中が 緩和されていることがわかった.このことから，地震時の 堤体変形やクラック等の堤体損傷を評価するに当たっ て, 本検討で得られた応力分布を参考に地震前の初期 応力の精度を向上させ, 地震時の堤頂損傷の耐震性 能評価の向上に努めていく必要がある.

さらに, コンクリート表面遮水壁型ロックフィルダムで はロック部の変形特性の評価が重要で, ロック部の見か けの変形係数は高圧縮応力下ではコア部よりも大きくな る傾向がある. 今後の堤高の高いコンクリート表面遮水 壁型ロックフィルダムの取り組みでは, 本検討で得られ たロック部の変形特性を参考に堤体変形解析の高度化 を図っていく必要がある.

以上のように, 実測值をもとに評価して得られた上記 の知見は, 湛水時の堤体安全性評価, ロックフィルダム の地震前の堤体挙動評価ならびにコンクリート表面遮 水壁型ロックフィルダムの堤体挙動解析の高度化に有 用なもので, ロックフィルダムの力学的挙動研究の発展 に寄与できるものである. 
表ー3 堤体の実測応力ならびにひずみ挙動のまとめ

\begin{tabular}{|c|c|c|}
\hline \multicolumn{2}{|r|}{ 区 分 } & 応力ひずみ挙動のまとめ \\
\hline \multirow[t]{5}{*}{$\begin{array}{l}\text { 堤体の応 } \\
\text { 力挙動 }\end{array}$} & 築堤時の応力 & $\begin{array}{l}\text { フィルタ部の鉛直応力は土被り厚の小さい時から鉛直応力が増加傾向を示した. コア } \\
\text { 部の鉛直応力は盛立の後半で低下する傾向を示し, フィルダムの角形の堤体形状に } \\
\text { よる応力低下の影響が顕著にみられた. 築堤時の応力は, 最小・最大主応力比がほぼ } \\
\text { 一定で増加する傾向を示した. }\end{array}$ \\
\hline & $\begin{array}{l}\text { 築堤完了時の鉛直 } \\
\text { 応力／土柱重量 }\end{array}$ & $\begin{array}{l}\text { フィルタ部の鉛直応力は土柱重量の } 0.8 \sim 1.5 \text { 倍, コア部は } 0.4 \sim 0.7 \text { 倍程度で, フィ } \\
\text { ルタ部とコア部の鉛直応力の差は約 } 2 \text { 倍程度を示し, 低土被り厚と高土被り厚で顕著 } \\
\text { な差を示さなかった. }\end{array}$ \\
\hline & \begin{tabular}{|l} 
築堤完了時のコア \\
部の鈆直応力低下
\end{tabular} & $\begin{array}{l}\text { 阿木川ダムにおける非線形築堤解析の結果，コア部の応力低下はフィルタ部への応力 } \\
\text { 集中が無い場合に対して, 約 } 1 \text { 割程度であることを示した. }\end{array}$ \\
\hline & $\begin{array}{l}\text { 放置期間中の鉛直 } \\
\text { 応力 }\end{array}$ & $\begin{array}{l}\text { コア部の鉛直応力はコア部の圧密沈下に伴って応力低下する傾向を示し, フィルタ部 } \\
\text { は逆に増加する傾向を示した. }\end{array}$ \\
\hline & 湛水時の鉛直応力 & $\begin{array}{l}\text { 上流フィルタ部の鉛直全応力は湛水に伴って低下する傾向を示し，湛水によって上流 } \\
\text { フィルタの集中が緩和される傾向を示した．なお，下流フィルタ部の鉛直全応力 } \\
\text { は湛水による下流側への変形により鉛直応力がやや増加する傾向を，コア部は若干増 } \\
\text { 加する傾向を示した. }\end{array}$ \\
\hline $\begin{array}{l}\text { 堤体のひ } \\
\text { ずみ挙動 }\end{array}$ & $\begin{array}{l}\text { 築堤完了時の鉛直 } \\
\text { ひずみ }\end{array}$ & $\begin{array}{l}\text { コアおよびロック部の鉛直ひずみは深さ方向に大きくなるが，コア部は増加傾向が深 } \\
\text { 部で低下する傾向を示し，ロック部では増加傾向が低下するケースと一定傾向のケー } \\
\text { スを示した. }\end{array}$ \\
\hline \multirow[t]{2}{*}{$\begin{array}{l}\text { 堤体の応 } \\
\text { 力ひずみ } \\
\text { 挙動 }\end{array}$} & $\begin{array}{l}\text { 築堤時のコア部の } \\
\text { 応力ひずみ }\end{array}$ & $\begin{array}{l}\text { コア部で実測された見かけの変形係数は, 鉛直応力約 } 0.5 \mathrm{MPa} \text { 以下では } 10 \text { 〜 } 30 \mathrm{MPa} \\
\text { と小さいが, それ以降では約 } 40 \sim 80 \mathrm{MPa} \text { と増加し, 盛立休止期間の圧密沈下を除け } \\
\text { ばさらに大きくなる傾向を示した. なお, 堤体上部の見かけの変形倸数は一定傾向で } \\
\text { 小さく, 堤体形状の影響の可能性が推察される. }\end{array}$ \\
\hline & \begin{tabular}{|l} 
築堤時のロック部 \\
の応力ひずみ
\end{tabular} & $\begin{array}{l}\text { ロック部で実測された見かけの変形係数は, 堤体材料によって約 } 30 \sim 60 \mathrm{MPa} \text { の差は } \\
\text { あるものの一定の傾向を示した. また, 鉛直応力約 } 1 \mathrm{MPa} \text { 以上ではロック部はコア部 } \\
\text { より見かけの変形係数が小さく, 高圧縮応力下では変形しやすい特徵を示した. } \\
\text { 味噌川ダムの底部ロック部の応力ひずみの傾向はコア部に類似した傾向を示し, 堤体 } \\
\text { 形状の影響の可能性が推察された. } \\
\text { ロック部の応力ひずみの関係を } \log (\sigma v) \sim \varepsilon v \text { 関係でみると, 等価な先行圧縮応力が } \\
0.2 \sim 0.5 \mathrm{MPa} \text { 付近にみられた. }\end{array}$ \\
\hline
\end{tabular}

\section{参考文献}

1）安田成夫, 小嶋光博, 中村昭: ロックフィルダムの土圧 挙動,第28回土質工学研究発表会, pp.231-232, 1993.6.

2) 坂本忠彦, 竹林征三, 中村昭, 安田成夫, 小嶋光博:ゾ ーン型ロックフィルダムの実測挙動と安全性評価, 大ダ ム, No.150, pp.51-61, 1994.

3）日本大ダム会議 技術委員会 地震時のダム安全分科 会: 既設ダムの耐震性能評価法の現状と課題, 大ダム, No.180 号, pp.3-70, 2002.7.

4）播田一雄, 米崎文雄, 佐藤信光, 染矢武彦, 小野紘一: コンクリートスラブの応カと変形について, 大ダム, No.175(2001-4), pp.87-95, 2001.

5）山口温朗, 小坪洋巳:德山ダム上流二次締切における CFRD の試験施工について, ダム日本, No.699, pp.39-64 , 2002.

6) Duncan,J.M., Chang,C.Y.: Nonlinear Analysis of Stress and Strain in Soil Mecanics, Journal of the Soil Mechanics and Foundations Division, ASCE, SM5, pp.1629-1653, 1970.

7) 森 吉昭, 内田善久, 中野 靖, 吉越 洋, 石黒 健, 太田秀樹: 現場転圧された粗粒材料の高応力下に おける圧縮性状と材料定数, 土木学会論文集, No.687
/III-56, pp.233-247，2001.9.

8）原田次夫, 松井家孝:ロックフィルダムの築堤中および たん水後の挙動, 土と基礎，25-5(231), pp.67-74， 1977.5.

9）吉越 洋, 井上泰行, 津田正寿, 内田善久, 藤山哲雄, 太田秀樹: ロックフィルダムの遮水ゾーンの長期沈下挙 動, 土木学会論文集, No.582 / III-41, pp.197-205, 1997.12.

10) 井上泰行, 内田善久, 望月直也, 石黒 健, 太田秀樹: ロックフィルダム遮水ゾーンの湛水後長期沈下メカニズ ム, 土木学会論文集, No.582 / III-41, pp.275-284, 1997.12.

11）佐藤信光, 米崎文雄, 大藪勝美, 太田秀樹, 中川浩二 :ロックフィルダムの実測変形挙動に関する検討, 土木 学会論文集, No.736 / III-63,pp.179-192, 2003.6.

12）土木学会:ダムの耐震設計と動的解析, 動的解析と耐 震設計, 第3巻, pp.3-108, 1989.7 .

13）唐沢成明, 島津義郎, 白川信之, 桑島孝暢 : ゾーン型 ロックフィルダムの挙動に関する一考察, 大ダム, No.150, pp.20-32, 1994.12.

14）建設省河川局開発課監修:フィルダムの耐震設計指針 (案), pp.13-67, 1991.3. 
15）佐藤信光, 米崎文雄, 龍岡文夫:ひずみ軟化理論を適 用したロックフィルダムの地震後残留沈下の検討, 土木 学会第 56 回年次学術講演会, pp.682-683. 2001.10.

16）電力土木技術協会: 改訂新版最新フィルダム工学, pp.253-323, 1981.3 .

17) Marsal, R. J. and Ramirez, E. G. : Performance of El Infiernillo Dam, Journal of the Soil Mechanics and Foundations Division, Vol 93, ASCE, SM4, pp.265-289, 1967.

18）坂本忠彦, 松本徳久, 福永和久:海外のCFRDの動 向, ダム技術, No.162, pp.8-22, 2000.3.

19）森富雄,白石幸久,松澤宏: 地中土圧および間隙水圧の 計測例,基礎工, Vol.12, No.5, pp.48-53, 1984.5.
20）笹川栄志, 松本徳久, 尾芦直人:ロックフィルダムにお ける漏水量, 変形, 温度の実測及び解析, 大ダム, No.100, pp.42-58, 1982.6.

21） 久納誠:フィルダムの実測值による応力・ひずみ解析,第 1回ダム工学研究発表会, pp.10-12, 1991.

22）岩片透:ゾーン型フィルタイプダムの透水性材料の力学 特性の評価に関する研究，東電設計技術資料， pp.137-142, 1987.9.

23）三浦哲彦, 村田秀一, 安福規之, 赤司六哉 : 粗粒材の 材料定数と応力ひずみ特性, 土と基礎, No.33-6, pp.13-18, 1985.

\title{
STUDY ON THE OBSERVED STRESS AND STRAIN OF ROCKFILL DAMS
}

\author{
Nobuteru SATO, Fumio YONEZAKI, Katsumi OOYABU, \\ Hideki OHTA and Koji NAKAGAWA
}

There are several themes in the mechanical behavior of a rock-fill dam. They are the stress concentration at the filter zone, the drop of the stress at the core zone, the highly sophisticated analysis method of the earthquake resistance of a rock-fill dam, and the new design method of a concrete-faced rock-fill dam (CFRD). In this study the stresses and strain behavior observed at the 4 rock-fill dams were compared with each other and analyzed from an overall viewpoint. The authors believe that the present investigation could provide useful information to dam design method and sophisticated analyses of dam body behavior. 